\title{
PHYTOCHEMICAL ANALYSIS AND EVALUATION OF ANTIMICROBIAL ACTIVITY IN THE WHOLE PLANT EXTRACTS OF GLORIOSA SUPERBA
}

\author{
JOTHI UCHIMAHALI ${ }^{1}$, ANJELIN JEBAMALAR ${ }^{1}$, GAJALAKSHMI DURAIKANNU ${ }^{2}$, SIVAKUMAR THIRUMAL ${ }^{3 *}$
}

${ }^{1}$ Department of Botany, Bharathiar University, Coimbatore, Tamil Nadu, India. ${ }^{2}$ Department of Chemistry, University College of Engineering, Villupuram, Tamil Nadu, India. ${ }^{3}$ Department of Botany, Annamalai University, Chidambaram and Thiru A. Govindasamy Government Arts College, Villupuram, Tamil Nadu, India. Email: drtsivanano@gmail.com

Received: 14 March 2019, Revised and Accepted: 01 May 2019

\section{ABSTRACT}

Objectives: The aim of this research work was to carry out the phytochemical screening and to evaluate the antibacterial and antifungal activity of the whole plant extract (shoot, flower, and tuber) of the flame lily (Gloriosa superba).

Materials and Methods: In the current work, phytochemicals were extracted from different parts of the plant using different solvents dimethyl sulfoxide, ethyl acetate, and ethanol (ETOH). These phytochemicals contained alkaloids, flavonoids, terpenoids, tannins, saponins, aromatic acids, phenolic compounds, xanthoproteins, triterpenoids, amino acids, philobatinins, carbohydrate, reducing sugar, and proteins and they were separated using standard methods. Furthermore, antimicrobial activities of methanolic separation were determined using various species of bacteria and fungi. Agar well diffusion method was used for the antimicrobial activity and the zone of the inhibition was analyzed.

Results: The evaluation of preliminary phytochemical screening of extracts indicated the presence of carbohydrates, reducing sugars, proteins, amino acids, steroids, flavonoids, terpenoids, saponins, alkaloids, tannins, and phlobatannins. Tuber extracts highlighted effective antibacterial and antifungal activities compared with shoot and flower extracts against all the tested bacteria and fungi. ETOH extract of the tuber observed highest antibacterial activity against Staphylococcus aureus (19 mm), followed by Escherichia coli (18 mm), Micrococcus luteus (17 mm), Pseudomonas aeruginosa (17 mm), and Salmonella abony $(16 \mathrm{~mm})$ when compared to shoot and flower extracts. G. superba tuber extracts highlighted effective antifungal activities compared with shoot and flower extracts against all the tested fungi. ETOH extract of the tuber observed highest antifungal activity against Rhizopus oryzae (20.17 mm), followed by Mucor Sp. (19.87 mm), Aspergillus niger (18.02), Candida krusei (17.98 mm), and Candida albicans (16.88 mm) as compared to shoot and flower extracts.

Conclusion: Results of the current studies flame lily ETOH extracts showed that the plant has significant antimicrobial activities. The strong antibacterial and antifungal activities of flame lily are due to the presence of tannins and flavonoids present in.

Keywords: Flame lily, Alkaloids, Phenolic compounds, Antibacterial, Antifungal activity.

(C) 2019 The Authors. Published by Innovare Academic Sciences Pvt Ltd. This is an open access article under the CC BY license (http://creativecommons. org/licenses/by/4. 0/) DOI: http://dx.doi.org/10.22159/ajpcr.2019.v12i6.33059

\section{INTRODUCTION}

Ayurveda is one of the essential systems of alternative and complementary medicine. Different drug formulations are used in Ayurvedic system of medicines. In addition to other herbal remedies, large portions of its medicines are based on domestic herbs. Complete and advanced knowledge of the medicinal plant is mandatory for everyone working in the Ayurvedic field to find and select the suitable plant for a particular disease [1]. In recent years, interest in medicinal plants has been greatly increased, and the West has taken this issue seriously [2]. The World Health Organization (WHO) presently encourages and promotes traditional medical treatments in national health programs, which are easily available at affordable prices and are culturally accepted. Furthermore, the WHO estimates that approximately one-third of the global population uses herbs and other forms of traditional medicines to treat ailment [3]. Plant-based drugs are safe because there are no or only few side effects [4]. However, the lack of quality control profiles is limited to accepting Ayurvedic drugs. The final product analysis profile has an impact on its performance and safety [5].

Gloriosa superba L., glory lily, flame lily, lily climbing, creeping lily belongs to the family Colchicaceae. Tropical Africa, southeastern Asia, and India were native to $G$. superba and also broadly cultivated in the world as ornamental plant. G. superba is used to treat various diseases and is conventionally used. Medicines of this plant with major secondary metabolism, tropolone type are present in alkaloids, seeds, and tubers [6].

In recent years, there has been a huge interest in the use of herbal medicines to cure diseases as there are no side effects compared to synthetic drugs. Flame lily is considered to be the resource of lily colchicines and gloriosine [7]. The flame lily exhibits a broad spectrum of functions to get rid of constipation, anti-inflammatory efficacy, antimicrobial, larvisic test, antibacterial energy, antithrombotic energy, antidepressant energy, enzyme resistance, and serpent bite, skin disease, and respiratory disorders [8-10]. Furthermore, it is found suitable for the treatment of injuries and sprains, bitterness, chronic injuries, hemorrhoids, cancers, epadons, nitrinal vaginal emission, leprosy, labor pain, and abortion [11]. It also cures injuries, skin problems, flu, inflammation, piles, blood disorders, lung contractions, general body toner, and poison [12].

Therefore, new drugs expect plant resources for an improved and cheaper alternative from natural products. Treatment standards of these plants are fixed in various phytocompounds by constructing a stable physiological activity in the human body [12]. Various parts of $G$. superba have different types of applications, in particular, in traditional medical practice. For the treatment of injuries and sprains, bitterness, chronic injuries, hemorrhoids, cancers, epadons, nitrinal 
vaginal emission, leprosy, labor pain and abortion [13]. Injuries, skin problems, flu, inflammation, piles, blood disorders, lung contractions, general body toner, poison [11]. The major aim of this work was focused to perform phytochemical and antimicrobial activities on the whole plant extracts of $G$. superba.

\section{MATERIALS AND METHODS}

\section{Plant materials}

The fresh whole plants (leaves, stem, flower, and tuber) were collected from Bharathiar University, Coimbatore 2013-2014, Tamil Nadu, India. This plant was identified and recognized from the Department of Botany, Annamalai University, Tamil Nadu, India. All new plants collected and separated were then washed out in tap water, dried in the shade and finely powdered, and stored in air-tight container

\section{Chemicals}

All chemicals were purchased by the SD Chemicals Company, Mumbai, and all chemicals were analytical grade.

\section{Phytochemical screening}

The bioactive compounds analysis of the dimethyl sulfoxide (DMSO), ethyl acetate (ETOAC), and ethanol (ETOH) of a flame lily whole plant extract was analyzed by standard methods as described [14-16]. The extract was analyzed for the presence of secondary metabolites (alkaloids, flavonoids, terpenoids, tannins, saponins, aromatic acids, phenolic compounds, xanthoproteins, triterpenoids, amino acids, philobatinins, carbohydrate, reducing sugar, and proteins).

\section{Chemical group tests of the extract}

Various chemical groups extracted were performed by phytochemical studies [14]. In each test, $10 \%(\mathrm{w} / \mathrm{v})$ extraction solution was taken personally to be tested.

\section{Active principle analysis}

- Test for steroids and terpenoids: $9 \mathrm{ml} \mathrm{ETOH}$ was added to extract and refluxed to for a few minutes. Each filtrate was concentrated in boiling water to $2.5 \mathrm{~mL} .5 \mathrm{~mL}$ of distilled water was added to a concentrated solution, and the mixture is allowed to stand for $1 \mathrm{~h}$ and the wax material is filtered. This filtrate was extracted using the separating funnel using $2.5 \mathrm{~mL}$ chloroform. $1 \mathrm{~mL}$ of concentrated $\mathrm{H}_{2} \mathrm{SO}_{4}$ was added to $0.5 \mathrm{~mL}$ chloroform extract in a test tube carefully. A reddish-brown interface showed steroids.

- The chloroform extract was evaporated and dehydrated to $0.5 \mathrm{ml}$ on a water bath and heated with $3 \mathrm{ml}$ of concentrated $\mathrm{H}_{2} \mathrm{SO}_{4}$ for $10 \mathrm{~min}$ on water bath. The presence of gray color showed terpenoids.

\section{Test for flavonoids}

About $20 \mathrm{mg}$ of the extract from each of different solvents with $10 \mathrm{ml}$ ETOAC is boiling water for 3 min. The mixture was filtered and the filtrate was used for the following tests:

- Ammonium test: $4 \mathrm{ml}$ of the filtrate was shaken with $1 \mathrm{~mL}$ liquid ammonia solution (1\%). The permitted layers were separated. A yellow color in the ammonia stack represented the presence of flavonoids.

- Test for alkaloids: The test solvent $(0.2 \mathrm{~g})$ was boiled through the $5 \mathrm{~mL}$ of $2 \% \mathrm{HCL}$ on the water bath. The mixture was filtered and to $1 \mathrm{~mL}$ filtrate two drops of the following reagents were added:

- Dragendorff's reagent: The formation of red precipitate confirms the presence of alkaloids

- Wagner's reagent: The creation of reddish-brown precipitate indicated the presence of alkaloids

- Hager's reagent: The development of yellow precipitates showed the presence of alkaloids.

- Test for saponins: $500 \mathrm{mg}$ of test solvent was boiled with $5 \mathrm{~mL}$ of distilled water for $5 \mathrm{~min}$. The hot solution was filtered and the filtrate was utilized for further test:

- Frothing test: $1 \mathrm{ml}$ of the above filtrate was added with $4 \mathrm{~mL}$ distilled water, shaken vigorously, and observed for the appearance of stable froth.
- Test for tannins: $2 \mathrm{~g}$ test solution was heated with $5 \mathrm{~mL}$ of $45 \% \mathrm{ETOH}$ for $5 \mathrm{~min}$. The chilled solution was filtered and the filtrate was used for next test:

- Lead-acetate test: $1 \mathrm{ml}$ of filtrate was diluted with three drops lead acetate mixture and cream gelatinous precipitate showed the presence of tannins.

- Ferric chloride test: $1 \mathrm{ml}$ filtrate was added with distilled water and diluted and two drops of ferric chloride were added. Transient greenish to black color confirmed the presence of tannins.

- Screening for phenols: To $1 \mathrm{ml}$ extract and $3 \mathrm{~mL}$ of distilled water, few drops of $10 \%$ aqueous ferric chloride solution was added and the development of blue or green color showed the presence of phenols.

- Macronutrient analyses: The test which would be shown subsequently was carried out to determine the presence of macronutrients in the climber of whole plant extract of $G$. superba.

- Test for carbohydrate: $100 \mathrm{mg}$ of the test solution was shaken vigorously with water, then filtered and the aqueous filtrate was mixed with few drops of Molisch's reagent, followed by concentrated $\mathrm{H}_{2} \mathrm{SO}_{4}(1 \mathrm{~mL})$ to form a layer below the aqueous solution. A brown ring at the interface indicated the presence of carbohydrates.

- Test for reducing sugar: $100 \mathrm{mg}$ of the test solution was shaken vigorously with $5 \mathrm{ml}$ of distilled water and filtered; the filtrate was mixed with equal volumes of Fehling solutions A and B then shaken vigorously. Brick red color precipitate confirmed the presence of reducing sugars.

\section{Test for protein}

\section{Burette test}

About $2 \mathrm{ml}$ of test solution was place in a test tube, then five drops of $1 \%$ hydrated copper sulfate and $2 \mathrm{~mL}$ of $40 \%$ sodium hydroxide were mixed and shaken vigorously. A purple color indicated the presence of proteins (presence of two or more peptide bonds).

\section{Antibacterial activity}

Bacterial strains of Salmonella abony, Pseudomonas aeruginosa, Micrococcus luteus, Staphylococcus aureus, and Escherichia coli were used and maintained in nutrient agar (HiMedia, Mumbai) slants at $4^{\circ} \mathrm{C}$. Mueller-Hinton agar (HiMedia, Mumbai) plates had been prepared, sterilized, solidified, and swabbed uniformly. In vitro antibacterial activity assay of aqueous DMSO, ETOAC, and ETOH was determined by way of agar well diffusion methods. The various concentrations of aqueous solvents 25,75 , and $125 \mu \mathrm{l}$ have loaded into the wells of all plates. All bacterial strains are S. abony, P. aeruginosa, M. luteus, $S$. aureus, and E. coli obtained from Rajah Muthiah Medical College, Annamalai University, Annamalai Nagar. Area of inhibition changed into measured $(\mathrm{mm})$ after incubating the plates at $37^{\circ} \mathrm{C}$ for $24 \mathrm{~h}$. Triplicates have been maintained.

\section{Fungal strains and inoculum quantification}

The selected plant fungal pathogens C. albicans MTCC No. 7315, C. krusei MTCC No. 3020, A. niger MTCC No. 5889, Rhizopus oryzae (MTCC No. 3690), and Mucor Sp. MTCC No.3340 were obtained from the Department of Medical Microbiology, Rajah Muthiah Medical College and Hospital, Annamalai University, Tamil Nadu, India. The selected fungi are important among pathogenic fungi with economic impact to plants. The fungal strains were retained on potato dextrose (PD) agar. Amended hemocytometer cell counting was employed for estimating the number of cells in each fungal culture [17]. The inoculum preparation involved in the growth of fungus on PD agar slants for 1 week at $35^{\circ} \mathrm{C}$. The slant was wiped off with a sterile cotton swap and shifted to a sterile tube with fresh PD broth $(50 \mathrm{ml})$. The sterile tubes were then dazed for $5 \mathrm{~min}$ and appropriate dilutions were made to estimate the number of cells by microscopic enumeration with a hemocytometer. The final inoculums concentration was maintained to approximately $1.0 \times 10^{6}$ cells $/ \mathrm{ml}$. 
Determining antifungal activity

Each well was filled with plant extracts $(100 \mathrm{~mL})$ serially diluted $50 \%$ and included by water in 96-well microtiter plates and $100 \mathrm{ml}$ of fungal cultures were added [18]. The amphotericin B was used as an antibiotic reference and $100 \%$ acetone was a negative control. The previous concentration of the acetone in the microplate formerly showed [19] that the fungus did not have any influence on fungal growth. A display of growth $40 \mathrm{ml}$ of $0.2 \mathrm{mg} /$ $\mathrm{ml} \mathrm{p}$-iodonitrotetrazolium violet (INT) dissolved in water and filled to the microplate well. The enclosed microplate was incubated for 3-5 days in the plastic bag at $100 \%$ relative humidity at $35^{\circ} \mathrm{C}$ after sealing a plastic bag to minimize fungal contamination in the laboratory. The minimal inhibitory concentration was recorded as the lowest concentration of extract that could prevent the development of antifungal growth. Colorless tetrazolium salt acts as an electron receiver and is inhibited by a red-colored formazan developed with biological active organisms [18]. If the growth of the fungal was prohibited, a well-known solution is clear or a significant reduction in the severity of the color after it is attached to the INT.

\section{Statistical analysis}

Experiments have been performed in triplicates and the results have been expressed as mean \pm standard deviation. The statistical analysis was made with origin software (OriginPro Evaluation, 2018).

\section{RESULTS AND DISCUSSION}

Qualitative phytochemical analysis

The bioactive chemicals examined in the shoots, flowers, and tubers of G. superba whole plant extracts revealed the presence, absence, and not detected of compounds as listed (Tables 1 and 2).

The present studies confirmed that the presence of alkaloids, flavonoids, terpenoids, tannins, saponins, aromatic acids, phenolic compounds, xanthoproteins, triterpenoids, amino acids, carbohydrate, reducing sugar, and proteins was observed in tuber extracts while reducing sugars, xanthoproteins, amino acid, philobatinins, and proteins were absent. No amino acids were detected in shoot, flower, and tuber extracts of $G$. superba. The shoot and flower extract of $G$. superba showed negative results for terpenoids and saponins as reported in Solanum torvum [20]. The tuber extract showed positive results for terpenoids, alkaloids, saponins, and sterols, phenols as mentioned in sweet potato,
Asparagus racemosus, elumpotti, Ormocarpum cochinchinense, Datura, Camellia sinensis, and Guazuma ulmifolia [21-28].

\section{Antibacterial activity}

Organic solvents DMSO, ETOAC, and ETOH of tuber extracts displayed more pronounced antibacterial activity than shoot and flower extract. Antibacterial activity extended with the increase inside the attention of the shoot, flower, and tuber extract. The maximum zone of inhibition $(19.00 \pm 0.45 \mathrm{~mm})$ was exhibited by ETOH tuber extract of $G$. superba. The DMSO, ETOAC, and ETOH tuber extract confirmed maximum area of inhibition in the various concentrations $(25,75$, and $125 \mu \mathrm{L} / \mathrm{ml})$ against shoot and flower as shown in Fig. 1.

This activity can be due to the potential ability of the secondary metabolites to shape a complex with extracellular proteins and with the cell wall of microorganism [29]. The inhibition effect of the methanol leaf extract, on the increase of bacteria, might be due to better solubility of these secondary metabolites, which showed the presence of a wide spectrum of antibiotic compounds [30]. The organic solvent of the plant extract (tuber) renders greater antibacterial ability than the

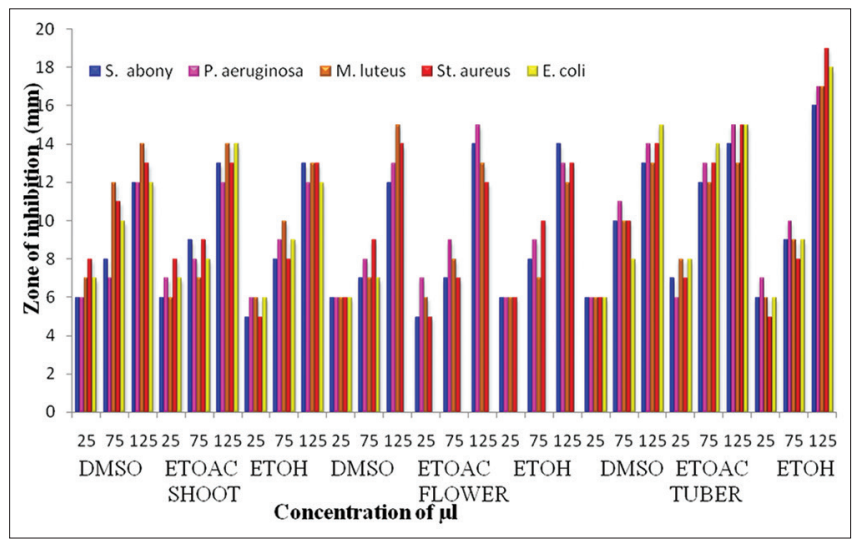

Fig. 1: Inhibition zone of three solvent extracts from shoot, flower, and tuber extracts of Gloriosa superba against five different bacterial pathogens

Table 1: Qualitative phytochemical analysis data in the shoot, flower, and tuber extracts of $G$. superba

\begin{tabular}{|c|c|c|c|c|c|c|c|c|c|c|c|}
\hline \multirow[t]{2}{*}{ S. No. } & \multirow{2}{*}{$\begin{array}{l}\text { Parts of plant } \\
\text { Test for }\end{array}$} & \multicolumn{3}{|l|}{ Shoot } & \multicolumn{4}{|l|}{ Flower } & \multicolumn{3}{|l|}{ Tuber } \\
\hline & & DMSO & ETOAC & ETOH & DMSO & & & ЕTOH & DMSO & ETOAC & ETOH \\
\hline 1 & Alkaloids & + & + & +++ & + & & + & +++ & + & + & +++ \\
\hline 2 & Flavonoids & - & - & - & - & & - & - & + & + & +++ \\
\hline 3 & Terpenoids & - & - & - & - & & - & - & + & ++ & +++ \\
\hline 4 & Tannins & + & + & +++ & + & + & + & +++ & + & + & + \\
\hline 5 & Saponins & - & - & - & - & & - & - & + & +++ & ++ \\
\hline 6 & Aromatic acids & ++ & +++ & + & - & & - & - & + & + & + \\
\hline 7 & Phenolic compounds & + & + & - & - & & - & - & + & ++ & +++ \\
\hline 8 & Xanthoproteins & - & - & - & - & - & & - & - & - & - \\
\hline 9 & Triterpenoids & - & - & - & - & & - & - & + & + & ++ \\
\hline 10 & Amino acids & - & - & - & - & & - & - & - & - & - \\
\hline 11 & Philobatinins & $\mathrm{Nd}$ & $\mathrm{Nd}$ & $\mathrm{Nd}$ & $\mathrm{Nd}$ & & $\mathrm{Nd}$ & $\mathrm{Nd}$ & $\mathrm{Nd}$ & $\mathrm{Nd}$ & $\mathrm{Nd}$ \\
\hline
\end{tabular}

- Absent, + low abundance, ++ Moderate abundance, +++ High abundances, Nd Not detected, DMSO: Dimethyl sulfoxide, ETOAC: Ethyl acetate, ETOH: Ethanol,

G. superba: Gloriosa superba

Table 2: Macromolecule analysis data in the shoot, flower, and tuber extracts of $G$. superbo

\begin{tabular}{|c|c|c|c|c|c|c|c|c|c|c|}
\hline \multirow[t]{2}{*}{ S. No. } & \multirow{2}{*}{$\begin{array}{l}\text { Parts of plant } \\
\text { Test for }\end{array}$} & \multicolumn{3}{|l|}{ Shoot } & \multicolumn{3}{|c|}{ Flower } & \multicolumn{3}{|l|}{ Tuber } \\
\hline & & DMSO & ETOAC & ЕTOH & DMSO & ETOAC & ЕТОН & DMSO & ETOAC & ETOH \\
\hline 1 & Carbohydrate & + & + & +++ & + & + & ++ & + & + & +++ \\
\hline 2 & Reducing sugar & + & + & ++ & + & + & ++ & + & + & +++ \\
\hline 3 & Proteins & $\mathrm{Nd}$ & $\mathrm{Nd}$ & $\mathrm{Nd}$ & $\mathrm{Nd}$ & $\mathrm{Nd}$ & $\mathrm{Nd}$ & $\mathrm{Nd}$ & $\mathrm{Nd}$ & $\mathrm{Nd}$ \\
\hline
\end{tabular}

- Absent, + low abundance, ++ Moderate abundance, +++ High abundances, Nd Not detected, DMSO: Dimethyl sulfoxide, ETOAC: Ethyl acetate, ETOH: Ethanol,

G. superba: Gloriosa superba 


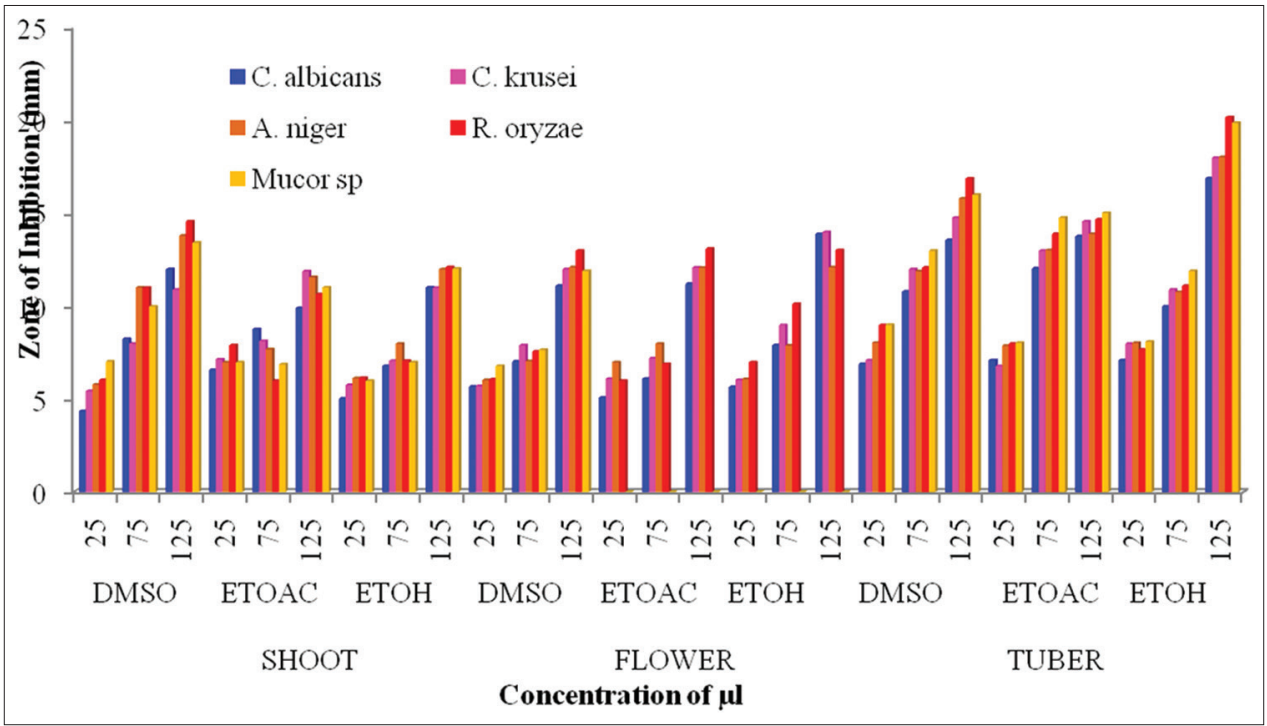

Fig. 2: Inhibition zone of three solvent extracts from shoot, flower, and tuber extracts of Gloriosa superba against six different fungal pathogens

shoot and flower extract. This result can be attributed to the polarity of the solvent used for extraction, essential bioactivity, and capability to diffuse in media utilized in assay $[31,32]$. Therefore, in many elements of the plant for herbal safety against microbial infection are packed with phytochemical substances. The phytochemical analysis revealed the presence of alkaloids, flavonoids, terpenoids, tannins, saponins, aromatic acids, phenolic compounds, xanthoproteins, triterpenoids, amino acids, carbohydrate, reducing sugar, and proteins in shoot, flower, and tuber extracts. Therefore, phytochemical products can be responsible for bacterial activity of $G$. superba.

\section{Antifungal activity}

The antifungal activity of the whole plant shoot, flower, and tuber extracts in different solvents was studied with the aid of agar well diffusion method against five pathogenic fungal species and measured the zone of inhibition for each fungal strain at various concentrations of 25, 75, and $125 \mu \mathrm{l} / \mathrm{ml}$ as shown in Fig. 2.

Antifungal activity of the tuber extracts of G. superba made with DMSO, ETOAC, and ETOH showed zone of inhibition against all the five fungal pathogens (C. albicans, C. krusei, A. niger, R. oryzae, and Mucor sp.) while none of the shoot and flower extracts made with three different solvents showed inhibition zones.

Herein, we report the antifungal activity of phytochemical extracts using DMSO, ETOAC, and ETOH from shoot, flower, and tuber of G. superb. It was found effective against $C$. albicans, $C$. krusei, A. niger, $R$. oryzae, and Mucor sp. In this study, it is observed that the zone of inhibition antifungal $(R$. oryzae $)$ activities of shoot, flower, and tuber ETOH extract $(14.06 \pm 0.57,12.98 \pm 0.35$, and $16.87 \pm 0.47 \mathrm{~mm}$ at 25,75 , and $125 \mu \mathrm{l} / \mathrm{ml}$ concentration, respectively) increased proportionately with the increase in the concentration of phytochemical extracts made using three different solvents from shoot, flower, and tuber of $G$. superba.

ETOHs solvent extracts of the tuber of G. superba showed highest inhibitory activity against selected fungi than DMSO and ETOAC. The current results confirmed with the previous study, DMSO, ETOAC, and ETOH tuber extract of $G$. superba which showed potential antifungal activity at $1 \mathrm{mg} /$ disc against to C. albicans, C. krusei, A. niger, R. oryzae, and Mucor sp. [33]. The methanol and ETOH of whole plant extract showed potential antifungal activity against to F equiseti, B. theobromae, and $C$. corchori [34]. The phytochemical screening revealed that plant secondary metabolites present in the extracts can agitate the fungal cell wall and also cause the discharge of cellular components such as ions and intracellular proteins which, in turn, stop the progress of the growth of fungi. The plant metabolites saponins, tannins, and alkaloids are known for antimicrobial activity which has been documented well [35]. Many scientists tried to explain the plausible mechanism of action of the antimicrobial activity of plant extracts. Triterpenoids or saponins present in the extracts could create pore-like structures and are responsible for the dissipation of membrane electrical potential or membrane proton motive force, and thus, membrane annihilation occurs [36].

\section{CONCLUSION}

Whole plant (shoot, flower, and tuber) extracts showed antibacterial and antifungal activity with maximum inhibition against to selected microorganisms. ETOHs of tuber exhibited maximum antibacterial and antifungal activity. Phytochemical screening revealed that alkaloids, triterpenoids, phenols, saponins, and flavonoids could be responsible for the antimicrobial activities of the G. superba whole plant extracts. It is evident from the current results that compounds of G. superba can be used as antimicrobial agents and ingredients in the human pathogenic diseased formulations in the different pharmaceutical fields.

\section{ACKNOWLEDGMENTS}

The authors are thankful to the Head, Department of Botany, Annamalai University, Annamalainagar, for providing the laboratory facilities.

\section{AUTHORS' CONTRIBUTIONS}

TS conceived the idea, participated in designing, supervised, and monitored the work progress. UJ and AJ conducted the experiments; TS, DG, and UJ drafted the manuscript for publication. All authors read and approved the final manuscript.

\section{CONFLICTS OF INTEREST}

The authors declare no conflicts of interest.

\section{REFERENCES}

1. Ballabh B, Chaurasia OP. Traditional medicinal plants of cold desert ladakh-used in treatment of cold, cough and fever. J Ethnopharmacol 2007;112:341-9.

2. Perumal Samy R, Ignacimuthu S, Sen A. Screening of 34 Indian medicinal plants for antibacterial properties. J Ethnopharmacol 1998;62:173-82.

3. Leena KP, Sreelakshmi KS. Phytochemical screening and in vitro cytotoxicity studies of Mussaenda frondosa Linn leaves. Res J Pharm 
Technol 2017; 10:4227-30

4. Sreesha NN, Alexeyena V, Meenu B, Greeshma R, Neeraja ED, et al. Comparative evaluation of Coriandrum sativum Linn And Apius graveolens for antimicrobial activity. Res J Pharm Technol 2017;10:541-4.

5. Shaikh S, Jain V. Development and validation of RP-HPLC method for the simultaneous determination of curcumin, piperine and camphor in an ayurvedic formulation. Int J Pharm Pharm Sci 2018;10:115-21.

6. Maroyi A, Van der Maesen LJ. Gloriosa superba L. (family colchicaceae): Remedy or poison? Med Plants Res 2011;5:6112-21.

7. Trease SE, Evans D. Colchicum seed and corn. In: Pharmacognosy. $12^{\text {th }}$ ed. London: Balliere Tindall; 1983. p. 593-7.

8. Ade R, Rai MK. Review: Current advances in Gloriosa superba L. Biodiversitas 2009;10:210-4

9. Alagesaboopathi C. Antimicrobial screening of selected medicinal plants in Tamilnadu, India. Afr J Microbiol Res 2011;5:617-21.

10. Hemaiswarya S, Raja R, Anbazhagan C, Thiagarajan V. Antimicrobial and mutagenic properties of the root tubers of Gloriosa superba Linn. Pak J Bot 2009;41:293-9.

11. Srivastava UC, Chandra V. Gloriosa superba Linn. (Kalihari)-an important colchicine producing plant. J Res Indian Med 1977;10:92-5.

12. Edeoga HO, Okwu DE, Mbaebie BO. Phytochemical constituents of some Nigerian medicinal plants. Afr J Biotechnol 2005;4:685-8.

13. Kala CP. Indigenous uses and sustainable harvesting of trees by local people in the pachmarhi biosphere reserve of India. Int J Med Aromat Plants 2011;1:153-61.

14. Evans WC. Trees and Evan Pharmacology. 14 th ed. Philadelphia, PA: W.B. Saunders Co. Ltd., 2000. p. 224-93.

15. Ghani A. Medicinal Plants of Bangladesh with Chemical Constituents and Uses. $2^{\text {nd }}$ ed. Dhaka, Bangladesh: Asiatic Society of Bangaladesh; 2003. p. 603.

16. Harbone JB. Phytochemical Methods-a Guide to Modern Technique of Plant Analysis. London: Chapmen and Hall; 1998. p. 182-90.

17. Aberkane A, Cuenca-Estrella M, Gomez-Lopez A, Petrikkou E, Mellado E, Monzón A, et al. Comparative evaluation of two different methods of inoculum preparation for antifungal susceptibility testing of filamentous fungi. J Antimicrob Chem 2002;50:719-22.

18. Eloff JN. Which extractant should be used for the screening and isolation of antimicrobial components from plants? J Ethnopharmacol 1998;60:1-8.

19. Eloff JN, Picard J, Masoko P. Resistance of animal fungal pathogens to solvents used in bioassays. S Afr J Bot 2007;73:667-9.

20. Prakash S, Jain AK. Antifungal activity and preliminary phytochemical studies of leaf extract of Solanum nigrumlinn. Int J Pharm Pharm Sci 2011;3:352-5

21. Kalita L, Dash B, Borah U, Deka J, Dash S. Preliminary phytochemical analysis and antimicrobial activity ethanolic extracts of dried fruits of Solanum torvum (Family-Solanaceae). Int J Curr Pharm Res
2017;9:123-6.

22. Sivakumar T. Phytochemical screening and gas chromatographymass spectroscopy analysis of bioactive compounds and biosynthesis of silver nanoparticles using sprout extracts of Vigna radiata L. And their antioxidant and antibacterial activity. Asian J Pharm Clin Res 2019;12:180-4

23. Sivakumar T, Gajalakshmi D. Phytochemical screening and gc-ms analysis of root extract from Asparagus racemosus L. Int J Pharm Sci Res 2014;5:5245-9.

24. Sivakumar T, Gajalakshmi D. In vitro antioxidant and chemical constituents from the leaves of Ormocarpum cochinchinense Elumbotti. Am J Plant Physiol 2013;8:114-22.

25. Sivakumar T, Gajalakshmi D. Gas chromatography-mass spectroscopy analysis of Ormocarpum cochinchinense leaf extract-traditional bone healing plants. Int J Pharm Res Bio Sci 2014;3:352-9.

26. Sivakumar T, Panneerselvam R. Triadiadomefon mediated changes in antioxidant and Indole alkaloid content in two species of Datura. Am J Plant Physiol 2011;6:252-60.

27. Senthilkumar SR, Sivakumar T. Green tea (Camellia sinensis) mediated synthesis of zinc oxide (ZNO) nanoparticles and studies on their antimicrobial activities. Int J Pharm Pharm Sci 2014;6:461-5.

28. Bhavani D, Malairajan S, Vanitha V. Physicochemical, phytochemicals and antioxidant evaluation of Guazuma ulmifolia fruit 2018. Int J Pharm Pharm Sci 2018;10:87-91

29. Kuete V, Nguemeving JR, Beng VP, Azebaze AG, Etoa FX, Meyer M. Antimicrobial activity of the methanol extracts and compounds from Vismia laurentii De Wild (Guttiferae). J Ethnopharmacol 2007; 109:372-9

30. Ikigai H, Nakae T, Hara Y, Shimamura T. Bactericidal catechins damage the lipid bilayer. Biochem Biophys Acta 1993;1147:132-6.

31. Jigna PA, Darshana JA, Sumitra CH. Efficacy of aqueous and methanol extracts of some medicinal plants for potential antibacterial activity. Turk J Biol 2005;29:203-10.

32. Sivakumar T, Gajalakshmi D, Subramanian VK, Palanisamy K. Tuber extract mediated biosynthesis of silver nanoparticles and its antioxidant, antibacterial activity. J Biol Sci 2015;15:68-7.

33. Nagarasan S, Boominathan M. Perspective pharmacological activities of Leucas aspera: An indigenous plant species. Indo Am J Pharm Res 2016;6:6567-72.

34. Akter M, Khan MA, Muhsin MD, Hamid K, Ullah MO, Bulbul IJ. In vitro studies on antibacterial, antifungal, and cytotoxic properties of Leucas aspera. Biol Med 2012;4:183-7.

35. Tschesche R. Advances in the chemistry of antibiotics substances from higher plants. Pharmacogn Phytochem 1970;3:274-89.

36. Netala VR, Ghosh SB, Bobbu PL, Dandu A, Tartte V. Triterpenoid saponins: A review on biosynthesis, applications and mechanism of their action. Int J Pharm Pharm Sci 2015;7:24-8. 